ADVANCES IN

PSYCHIATRY \& NEUROLOGY

POSTE⿱丷⿻尸丨

Psychiatrii i Neurologii

Correspondence to/

Adres do korespondencji:

Ewelina Dziurkowska

Katedra i Zakład Chemii Analitycznej

Gdański Uniwersytet Medyczny

al. Gen. J. Hallera 107

80-416 Gdańsk

tel.: +48583491526

e-mail: elewajs@gumed.edu.pl

Submitted/Otrzymano: 6.07 .2016

Accepted/Przyjęto do druku: 8.12.2016

\section{PUBLIC PERCEPTION OF A DANGEROUS PERSON IN PSYCHOTIC EXACERBATION ON THE EXAMPLE OF A COURT EXPERT JUDGEMENT CASE}

SPOŁECZNY ODBIÓR NIEBEZPIECZNEJ OSOBY W ZAOSTRZENIU PSYCHOTYCZNYM NA PRZYK ŁADZIE PRZYPADKU ORZECZNICZEGO BIEG $Ł Y C H$ SĄDOWYCH

\author{
Maciej Dziurkowski', Ewelina Dziurkowska², \\ Maciej Zbyszkowicz ${ }^{3}$
}

'Department for Treatment of Addictions with Subdepartment for Treatment of the Alcohol Withdrawal Syndrome, Stanisław Kryzan Hospital for the Nervously and Mentally III in Starogard Gdański, Poland

${ }^{2}$ Department and Unit of Analytical Chemistry, Gdańsk Medical University, Poland ${ }^{3}$ Department of Psychiatry, Specialist Independent Public Health Care Centre in Lębork, Poland

'Oddział Leczenia Uzależnień z Pododdziałem Leczenia Alkoholowych Zespołów Abstynencyjnych, Szpital dla Nerwowo i Psychicznie Chorych im. Stanisława Kryzana w Starogardzie Gdańskim, Polska

${ }^{2}$ Katedra i Zakład Chemii Analitycznej, Gdański Uniwersytet Medyczny, Polska ${ }^{3}$ Oddział Psychiatryczny, SPS ZOZ w Lęborku, Polska

\begin{abstract}
Purpose: The present paper describes a case of a patient who committed a criminal offence and was then judged by the media, and especially by web surfers. Mental illness of the patient was not taken into account, this possibility having been treated as a way getting away with the crime. The purpose of the present paper was to demonstrate stigmatisation of the mentally ill, which stems primarily from the ignorance of society.

Case description: According to the case files, the suspect was a 32-year old male with higher education who, during a visit to his family in Canada, had a "nervous breakdown" and returned to Poland to be admitted to a psychiatric hospital. After a week, he was discharged from hospital. After 8 months, he had a recurrence of the illness and was once more referred to mandatory treatment. According to the medical documentation, the suspect suffered from an acute polymorphic psychotic disorder with symptoms of schizophrenia. During his stay in hospitals, he uttered delusions of remote control, persecution, reference and grandeur. In the course of hospitalisation, he was aggressive towards the environment and had auditory hallucinations. After approximately two months of the date of leaving the hospital, the subject discontinued his medication. As a result of recurrence of the illness and while driving a car at an excessive speed, he caused a major traffic accident, endangering the lives and health of many people.

Comment: On the basis of the case files, the available medical documentation and the conducted judicial and psychiatric examination, court experts concluded that the suspect was mentally ill, i.e. that he suffered from paranoid schizophrenia. However, he was not mentally impaired, albeit, at the time of committing the act he was accused of, he was completely unable to recognise the meaning of his actions and make decisions concerning the way he behaved.
\end{abstract}

Key words: paranoid schizophrenia, acute psychosis, stigmatisation. 
Public perception of a dangerous person in psychotic exacerbation on the example of a court expert judgement case

Społeczny odbiór niebezpiecznej osoby w zaostrzeniu psychotycznym na przykładzie przypadku orzeczniczego biegłych sądowych

\section{Streszczenie}

Cel: W pracy opisano przypadek pacjenta, który dokonał czynu karalnego. Został osądzony przez media, a w szczególności przez osoby aktywne w Internecie. Nie brano pod uwagę choroby psychicznej podejrzanego - taka możliwość była traktowana jako sposób wykpienia się od odpowiedzialności. W artykule chciano wykazać stygmatyzację osób chorych psychicznie, która wynika przede wszystkim z niewiedzy społeczeństwa.

Opis przypadku: Z akt sprawy wynikało, że podejrzanym jest 32-letni mężczyzna, z wykształceniem wyższym, który podczas pobytu u rodziny w Kanadzie miał „załamanie nerwowe”, wrócił do kraju i trafił do szpitala psychiatrycznego. Po tygodniu opuścił szpital, po 8 miesiącach wystąpił u niego nawrót choroby. Został ponownie przymusowo skierowany na leczenie. Z dokumentacji medycznej wynikało, że podejrzany cierpi na ostre wielopostaciowe zaburzenia psychotyczne z objawami schizofrenii. W trakcie pobytu w szpitalach wypowiadał urojenia oddziaływania, prześladowcze, odnoszące i wielkościowe. W trakcie hospitalizacji był agresywny w stosunku do otoczenia, halucynował słuchowo. Po około dwóch miesiącach od opuszczenia szpitala badany odstawił leki. W wyniku nawrotu choroby, poruszając się samochodem z nadmierną prędkością ulicami Sopotu, umyślnie spowodował katastrofę w ruchu lądowym zagrażającą życiu lub zdrowiu wielu osób.

Komentarz: Na podstawie danych z akt sprawy, dostępnej dokumentacji medycznej oraz przeprowadzonego badania sądowo-psychiatrycznego biegli stwierdzili, że podejrzany jest chory psychicznie - cierpi na schizofrenię paranoidalną. Nie jest natomiast upośledzony umysłowo, a w chwili popełnienia zarzucanego mu czynu miał zniesioną całkowicie zdolność do rozpoznania jego znaczenia i pokierowania swoim postępowaniem.

Słowa kluczowe: schizofrenia paranoidalna, ostra psychoza, napiętnowanie.

\section{PURPOSE}

Mentally ill people often meet with rejection and stigmatisation in connection with their illness. It has to do mainly with ignorance and lack of understanding of processes that take place in their behaviour during exacerbation of symptoms of their illness. It particularly applies to people who suffer from schizophrenia.

Additionally, if they commit a criminal offence, despite that their state of health precludes the ability to recognise its meaning, they do not find any understanding in society. It is especially visible today when news spreads with enormous speed in the media, most of all on the Internet. Usually, it is exactly there that we feel impersonal and unpunishable in our judgements. Scientists have been pointing out the stigmatisation of mentally ill people as well as the fact that we distance ourselves from them and their stereotypisation $[1,2]$. Stigmatisation and isolation of mentally ill people, primarily those suffering from schizophrenia, is not only true in the case of Poland. Studies comparing the approach to ill people in Germany and several largest cities in Siberia confirmed that patients suffering from schizophrenia had been perceived as dangerous and unable to control their emotions as well as that they should have been isolated. Nevertheless, cultural differences were visible in the willingness to provide help to such people and in the approach of society to penalising mentally ill people for crimes they had committed. In the case of more developed countries such as Germany, the media has a large impact on the attitude of society towards schizophreniacs, putting emphasis on the relationship between crimes committed by mentally ill people with their state of health [3].

\section{CEL}

Osoby chore psychicznie w związku ze swoją chorobą najczęściej spotykają się z odrzuceniem oraz stygmatyzacją. Związane jest to przede wszystkim $z$ niewiedzą i niezrozumieniem procesów, jakie zachodzą w ich zachowaniu w trakcie zaostrzenia się objawów choroby. Dotyczy to zwłaszcza osób cierpiących na schizofrenię.

Dodatkowo, jeżeli dojdzie do popełnienia przez nie czynu karalnego, mimo że stan ich zdrowia wyklucza zdolność do rozpoznania jego znaczenia, nie znajdują one zrozumienia w społeczeństwie. Jest to szczególnie widoczne dzisiaj, kiedy informacje rozprzestrzeniają się z ogromną szybkością w mediach, przede wszystkim w Internecie. Zazwyczaj właśnie tam czujemy się bezosobowi i bezkarni w swoich osądach. Od wielu lat naukowcy wskazują na stygmatyzację osób chorych psychicznie, a także dystansowanie się od nich i ich stereotypizację $[1,2]$. Stygmatyzacja i izolacja osób chorych psychicznie, przede wszystkim cierpiących na schizofrenię, nie dotyczy wyłącznie Polski. Badania porównujące podejście do osób chorych w Niemczech oraz kilku największych miastach na Syberii potwierdziły, że pacjenci cierpiący na schizofrenię są postrzegani jako niebezpieczni, niepanujący nad swoimi emocjami i że powinni być izolowani. Aczkolwiek widoczne były różnice kulturowe w chęci niesienia pomocy takim osobom i w podejściu społeczeństwa do karania osób psychicznie chorych za popełnione przez nich przestępstwa. W przypadku krajów bardziej rozwiniętych, takich jak Niemcy, duży wpływ na stosunek społeczeństwa do schizofreników mają media, które kładą nacisk na związek przestępstw popełnianych przez osoby chore psychicznie $z$ ich stanem zdrowia [3]. 
A few years ago in Poland and other European countries, a social awareness campaign on mental illnesses and functioning of people who suffer from them started. $15 \mathrm{Sep}-$ tember has been the Day of Solidarity with Mentally Ill People since 2002. At the time, happenings, concerts, public readings and auctions of ill people's works took place. However, central celebration of the Day of Solidarity with Mentally Ill People has been reduced to the local level since 2005. Currently, campaigns aimed at reducing the stigmatisation of mentally ill people are being carried out in several largest cities only, Gdańsk not being one of them, unfortunately [4].

This publication describes the case of a patient who, as a result of recurrence of his mental illness, drove his passenger car at high speed on a summer evening along the Monte Cassino promenade in Sopot, ramming pedestrians. Once the news had been presented in the media, the patient was publically lynched not only on the Internet, but also on television and in the press.

The state of his health was so serious that court experts issued a concurring opinion on the basis of one examination at the Remand Centre that he suffered from paranoid schizophrenia and required immediate placement in psychiatric hospital and, due to diagnosed mental illness, judicial and psychiatric detention in a highsecurity psychiatric hospital department.

\section{CASE DESCRIPTION}

Patient $\mathrm{L}$. was born and raised in a normal, intellectual family as the first out of two children. Both parents are alive and healthy; no mental disorders having been diagnosed in the family or alcohol abuse. The court experts did not have any information on birth and early childhood development. The patient finished higher education with two majors, did not serve in the military, had no children, was a bachelor and had been living in a "loose" relationship with a younger woman. He did not abuse alcohol and, according to his claims, he was drinking a few beers a week since he had been 18. After drinking alcohol, he is calm, albeit he sometimes is aggressive when drinking vodka. He occasionally smoked marijuana. He was not sentenced by a court. He never suffered a head injury with loss of consciousness, denied the occurrence of seizures, suffered from meningitis/nighttime bedwetting/nervous tics or underwent surgical procedures. He did not make suicide attempts either.

After graduation, the subject travelled to Canada to his family. As a result of a nervous breakdown he underwent there, he came back to Poland. During the flight, he was very anxious - he was afraid of other passengers who, as he claimed, had been looking at him in a strange manner, which had caused him to feel unbearable physical pain. Due to weird behaviour and psychomotor agitation in the aeroplane, he was detained at the Warsaw Airport and hospitalised in a psychiatric hospital by a period of one week. The recurrence of the illness took place after
Kilka lat temu w Polsce oraz w innych krajach Europy rozpoczęto program uświadamiania społeczeństwa na temat chorób psychicznych, a także funkcjonowania osób nimi dotkniętych. Od 2002 r. dzień 15 września jest Dniem Solidarności z Osobami Chorymi Psychicznie. Wtedy to w całym kraju odbywały się liczne happeningi, koncerty, publiczne odczyty oraz aukcje prac osób chorych. Jednak od 2005 r. centralne obchody zredukowano do rangi lokalnej. Aktualnie programy mające na celu zmniejszenie stygmatyzacji osób chorych psychicznie prowadzone są tylko w kilku największych miastach. Niestety nie ma wśród nich Gdańska [4].

$\mathrm{W}$ pracy przedstawiono przypadek pacjenta, który $\mathrm{w}$ wyniku nawrotu choroby psychicznej wykonał przejazd $\mathrm{z}$ dużą prędkością $\mathrm{w}$ wakacyjny wieczór po deptaku Monte Cassino w Sopocie samochodem osobowym, taranując przechodniów. Po przedstawieniu informacji $\mathrm{w}$ mediach chory został publicznie zlinczowany nie tylko w Internecie, lecz także w telewizji i prasie.

Stan zdrowia mężczyzny był na tyle poważny, że biegli na podstawie jednorazowego badania $w$ areszcie śledczym wydali zgodną opinię, iż cierpi on na schizofrenię paranoidalną i wymaga pilnego umieszczenia w szpitalu psychiatrycznym oraz $-\mathrm{z}$ uwagi na zdiagnozowaną chorobę psychiczną - internacji sądowo-psychiatrycznej w warunkach oddziału szpitalnego o wzmocnionym stopniu zabezpieczenia.

\section{OPIS PRZYPADKU}

Pacjent L. urodził się i wychował w rodzinie prawidłowej, inteligenckiej, jako pierwszy z dwojga dzieci. Oboje rodzice żyją, są zdrowi, w rodzinie nie stwierdzono zaburzeń psychicznych ani nadużywania alkoholu. Informacje na temat porodu i rozwoju wczesnodziecięcego były nieznane biegłym. Pacjent ukończył dwa kierunki studiów, nie odbył służby wojskowej, jest bezdzietnym kawalerem od dwóch lat pozostającym w „luźnym” związku z młodszą kobietą. Nie nadużywa alkoholu. Jak twierdził, pije od 18. roku życia raz na tydzień kilka piw. Po spożyciu alkoholu jest spokojny, choć po wódce rzadko, ale bywa agresywny. Zdarzało mu się palić marihuanę. Nie był karany sądowo. Nigdy nie doznał urazu głowy z utratą przytomności, negował występowanie stanów drgawkowych, zapalenia opon mózgowo-rdzeniowych, zabiegów chirurgicznych, a także moczenia nocnego czy tików nerwowych. Nie podejmował również prób samobójczych.

Po ukończeniu studiów opiniowany wyjechał do rodziny do Kanady. W wyniku przebytego tam załamania psychicznego powrócił do kraju. W trakcie przelotu był w niepokoju, bał się współpasażerów, którzy - jak twierdził - dziwnie na niego patrzyli, co powodowało u niego ból fizyczny, którego nie mógł znieść. W wyniku dziwacznego zachowania i pobudzenia psychoruchowego w samolocie został zatrzymany na lotnisku w Warszawie 
Public perception of a dangerous person in psychotic exacerbation on the example of a court expert judgement case

Społeczny odbiór niebezpiecznej osoby w zaostrzeniu psychotycznym na przykładzie przypadku orzeczniczego biegłych sądowych

about 8 months when he once again suffered psychomotor agitation, did not sleep at night, listened to music at high volume levels or take the prescribed medicine. He claimed that he had written a film script and that was why he had hit his father, this having been written in the said film script. He felt he had been an outstanding film director anointed by Tarantino and Buddhist monks. He was then forcibly taken to a psychiatric department.

He was afraid of his parents, very lively and agitated. In both health care institutions, he was diagnosed with schizophrenia and it was recommended that he be treated with olanzapine and risperidone. After two-month treatment, he discontinued his medicine, since, as he claimed, it had made him fell asleep and interfered with his Buddhist meditation. He was living alone and changed jobs several times. A few days before the incident, his father noticed that his son had started to behave in a strange manner, avoided contact and became withdrawn.

On the day of the incident, the subject did not take any medicine or drugs, nor did he drink alcohol (which was confirmed by toxicological tests). He was supposed to star in one of the film scenes, as per his own film script, in which he was to pull off an airport runway drive. He claimed that the role had been agreed on with Mr Tarantino and the film script had been approved by the Hollywood. He stopped on his way to pick up his girlfriend, but she refused to take part in the filming. Rushing to the film set in Sopot, he entered a tunnel and then darkness fell upon him. He was unable to tell what had happened subsequently as the next thing he recalled was the police station. On the next day, during medical examinations, the patient added that he had intentionally entered the Monte Cassino street and counted up the pedestrians he had hit in order to achieve the second stage of enlightenment. On the same day, the subject's father found in his son's apartment a letter of termination of an employment contract.

\section{Psychiatric examination}

The court experts read the medical documentation on the subject in the form of a result of computer tomography of the head whereby no post-traumatic changes in the area of the brain or fractures in the cranial vault had been identified. The conducted RTG examination did not show any fracture fissures either. Moreover, physicians analysed medical records from both hospitals where the patient had been treated.

\section{Course of the examination}

The subject was led in by prison officers and took the indicated place. He was wearing clothes which he had torn himself. He was answering questions after longer periods of steady thought, talking in muted voice. He was listening out and was characterised by poor facial expressions and gesticulation. i hospitalizowany w szpitalu psychiatrycznym przez tydzień. Nawrót choroby nastąpił po ok. 8 miesiącach, kiedy to ponownie był pobudzony psychoruchowo, nie spał w nocy, słuchał głośno muzyki i nie przyjmował przepisanych leków. Twierdził, że pisze scenariusz. Uderzył ojca, uzasadniając to tym, że tak było napisane w scenariuszu. Czuł się wybitnym reżyserem namaszczonym przez Tarantino i mnichów buddyjskich. Wówczas trafił pod przymusem na oddział psychiatryczny.

Bał się rodziców, był bardzo żywy i pobudzony. W obu placówkach rozpoznano u niego schizofrenię i zalecono leczenie olanzapiną i risperidonem. Po dwumiesięcznej kuracji odstawił leki, gdyż - jak twierdził - usypiały go i przeszkadzały w medytacji buddyjskiej. Mieszkał sam, kilkakrotnie zmieniał pracę. Na kilka dni przed zajściem ojciec pacjenta zauważył, że zaczął się on dziwnie zachowywać, unikał kontaktu i stał się wycofany.

W dniu zajścia badany nie przyjmował żadnych leków ani środków odurzających, nie pił alkoholu (co potwierdziły badania toksykologiczne). Miał odegrać jedną ze scen filmu, według własnego scenariusza, w której odbywał rajd po pasie startowym lotniska. Twierdził, że rola została uzgodniona $\mathrm{z}$ panem Tarantino, a scenariusz zaakceptowany przez Hollywood. W drodze zajechał po swoją dziewczynę, ale ta odmówiła wzięcia udziału w nagraniu. Pędząc na plan filmowy w Sopocie, wjechał do tunelu i wtedy nastała ciemność. Nie był w stanie stwierdzić, co nastąpiło później. Pamięta dopiero posterunek policji. Następnego dnia w trakcie badań lekarskich pacjent podał, iż specjalnie wjechał na ulicę Monte Cassino i liczył potrąconych przechodniów, aby osiągnąć drugie oświecenie. Tego samego dnia ojciec badanego znalazł w jego mieszkaniu wypowiedzenie $\mathrm{z}$ pracy.

\section{Badanie psychiatryczne}

Biegli zapoznali się z dokumentacją medyczną opiniowanego w postaci wyniku badania tomografii komputerowej głowy, w opisie którego nie stwierdzono zmian pourazowych w obrębie mózgowia ani złamań w kościach sklepienia czaszki. Również przeprowadzone badanie RTG nie wykazało obecności szczeliny złamania. Ponadto lekarze przeanalizowali historie choroby pochodzące $\mathrm{z}$ obu szpitali, w których pacjent był leczony.

\section{Przebieg badania}

Opiniowany został wprowadzony przez funkcjonariuszy służby więziennej i zajął wskazane miejsce. Był w podartej przez siebie odzieży. Odpowiadał na pytania po dłuższym namyśle jednostajnym, ściszonym głosem. Nasłuchiwał i charakteryzował się ubogą mimiką oraz gestykulacją. 


\section{Somatic state}

The subject was characterised by correct construction of the body. His motor system was functioning correctly. He did not have any self-mutilation scars or tattoos. Neurological examination did not show characteristics of focal damage to the central nervous system or hemiparesis.

\section{Mental condition}

The subject reluctantly established verbal contact, was bizarre in his behaviour and gestures (lying down on a table, scratching all over his body, pulling his clothes), his talk remained poor. With a smile on his face and staring at one point, he was talking about the incident, which proved that he was inappropriate in his behaviour and facial expressions. During the examination, he was very anxious, with intensified fear, listening closely and autistic. He was focused on his own internal experiences and indifferent to the stimuli coming from the environment. He was answering physicians' questions after longer periods of thought. His conscience was clear, but he did not exactly know where he was or what time it was. In contrast, he had complete orientation as far as his own self was concerned. Furthermore, the train of thought of the subject was accelerated. He showed acute psychotic symptoms in the form of delusions of reference and grandeur. He claimed he had to finish the film, Tarantino and his Buddhist guru giving him appropriate instructions. He complained that he could not get any peace and despite that had to go back to work. Moreover, he said he was healthy and did not need any medicine. In the course of the examination, he also showed auditory hallucinations of imperative nature (voices of adult men providing him with advice as to the behaviour towards the physicians).

The court experts determined that the intellect of the subject was normal; he was characterised by coldness and emotional withdrawal as well as flat affect. He also showed disturbed recent memory and disturbed focus of attention. Moreover, his cause-and-effect thinking was established to have been impaired. His mood was indifferent, but with no suicidal thoughts. Furthermore, the subject was characterised by altered instinctual life in terms of sleep and appetite (many days of starvation and insomnia) as well as by disintegration of personality (ambitendency, ambivalence and ambisentence). He was not critical of his own state of health nor did he see any need for treatment.

\section{Expert medical opinion}

Having read the case files and the available medical documentation as well as having conducted the judicial and psychiatric examination, the court experts diagnosed the subject was paranoid schizophrenia. However, he was determined not to have been mentally impaired, however, at the time of committing the act he was accused of, he was

\section{Stan somatyczny}

Badany cechował się prawidłową budową ciała. Układ ruchu sprawny, na ciele brak blizn po samouszkodzeniach czy tatuaży. Badanie neurologiczne nie wykazało cech ogniskowego uszkodzenia ośrodkowego układu nerwowego czy niedowładu stronnego.

\section{Stan psychiczny}

Badany niechętnie nawiązywał kontakt słowny, był dziwaczny w zachowaniu i gestach (kładzenie się na stole, drapanie po całym ciele, szarpanie odzieży), jego mowa pozostawała uboga. $\mathrm{Z}$ uśmiechem wpatrzony $\mathrm{w}$ jeden punkt opowiadał o zajściu, co świadczyło o tym, iż jest niedostosowany w zachowaniu i mimice. $\mathrm{W}$ trakcie badania był w znacznym niepokoju, z nasilonym lękiem, nasłuchujący i autystyczny, skupiony na własnych wewnętrznych przeżyciach, a obojętny wobec bodźców płynących z otoczenia. Na pytania lekarzy odpowiadał po dłuższym namyśle. Jego świadomość była jasna, niedokładnie orientował się co do miejsca i czasu. Natomiast co do własnej osoby orientacja była pełna. Tok myślenia badanego był przyspieszony. Opiniowany prezentował ostre objawy psychotyczne w postaci urojeń ksobnych i wielkościowych. Twierdził, że musi ukończyć film, a Tarantino i jego buddyjski guru dają mu odpowiednie wskazówki. Narzekał, że nie ma spokoju, a musi wrócić do pracy. Ponadto jest zdrowy i nie potrzebuje żadnych leków. W trakcie badania prezentował również omamy słuchowe o charakterze imperatywnym (głosy dorosłych mężczyzn udzielające mu wskazówek co do zachowania wobec lekarzy).

Biegli określili, że intelekt opiniowanego był w normie; cechowały go chłód i wycofanie emocjonalne, a także bladość afektu. Wykazywał również zaburzoną pamięć świeżą i koncentrację uwagi. Ponadto myślenie przyczynowo-skutkowe określono jako zaburzone, nastrój obojętny, ale bez myśli suicydalnych. Opiniowany charakteryzował się również zmienionym życiem popędowym w zakresie snu i łaknienia (wielodniowe głodzenie się i bezsenność), a także osobowością $\mathrm{w}$ rozpadzie (ambitendencja, ambiwalencja i ambisentencja). Nie wykazywał krytycyzmu co do stanu własnego zdrowia, nie widział także konieczności leczenia.

\section{Orzeczenie}

Biegli sądowi po zapoznaniu się z aktami sprawy, dostępną dokumentacją medyczną oraz po przeprowadzeniu badania sądowo-psychiatrycznego rozpoznali u obserwowanego schizofrenię paranoidalną. Nie stwierdzili natomiast upośledzenia umysłowego. Ponadto w chwili popełnienia zarzucanego badanemu czynu zdaniem lekarzy 
Public perception of a dangerous person in psychotic exacerbation on the example of a court expert judgement case

Społeczny odbiór niebezpiecznej osoby w zaostrzeniu psychotycznym na przykładzie przypadku orzeczniczego biegłych sądowych

completely unable to recognise the meaning of his actions and make decisions concerning the way he behaved.

\section{COMMENT}

This publication describes the case of a patient who was sentenced by the public, Internet users and the media before psychiatric examinations had been carried out. On the day he performed his rally along the Monte Cassino street in Sopot, Internet forums buzzed with negative messages. The patient's illness was not taken into account, such a possibility having been treated as a way to avoid responsibility for the act. The state of the patient was so serious and clear from the viewpoint of diagnostics as well as supported by previous medical documentation that the court experts did not make a request for additional examinations nor for observation in psychiatric hospital - they issued their opinion after one examination. Analysis of comments of just one newspaper's website proved deep hatred towards people committing offences as a result of mental illnesses. For large part of society, and in particular for that which frequently posts messages on Internet forums, one examination and a clear diagnosis proved that the suspect had wanted to avoid responsibility and that his family had had some connections with the public prosecutor's office or the court experts. The following messages can serve as evidence of the above (original spelling was kept): "they're all very sane, interesting to know how much the court experts were paid by his mammy", "he's got a high profile mammy so they've made a schizo out of the mummy's boy so he wouldn't get framed... that's the whole story! You've got connections so they can kiss your a... That's the truth sick country and the system!", "From the beginning of the "Monte street rally", it was clear that the perpetrator wouldn't be held accountable for his act. Writing about him, it was said how intelligent, resourceful and hard-working he was... Can a mother protect an adult scallywag? "Insane" is a legal term after all, not a medical one... That is: they've written a lot to help the perpetrator responsible for the "human hunt" in the Monte street!!!", "An insane person is not able to perform such manoeuvres or have such a control over a vehicle", "if he had tried to run away from the crashed car, it meant that he was sane and knew that he had done wrong" [5].

There was only one message among the comments which explained the action of the perpetrator in terms of a mental illness, but it was quickly ridiculed.

The Internet observers and journalists questioned the correctness of the court experts' opinion, and the aggression which accompanied its publication proved lack of any education on mental illnesses. One of the journalists from Tricity's daily newspaper described the incident in the following way: "From the description of the incident, it appeared that it was probably not a mistake or a momentary blackout of the driver, nor was it loss of mental capacity, but a planned operation. The way in which the perpetrator was miał on zniesioną całkowicie zdolność do rozpoznania jego znaczenia i pokierowania swoim postępowaniem.

\section{KOMENTARZ}

W pracy przedstawiono przypadek pacjenta, który publicznie, medialnie został skazany, zanim przeprowadzono badania psychiatryczne. W dniu, kiedy dokonał rajdu po ulicy Monte Cassino w Sopocie, fora internetowe zawrzały od negatywnych wpisów. Nie brano pod uwagę choroby pacjenta - taką możliwość traktowano jako chęć uniknięcia odpowiedzialności za czyn. Stan pacjenta był na tyle poważny i jednoznaczny diagnostycznie oraz poparty wcześniejszą dokumentacją medyczną, że biegli nie wnioskowali o dodatkowe badania ani obserwację w szpitalu psychiatrycznym i po jednorazowym badaniu wydali opinię. Analiza komentarzy tylko jednej ze stron internetowych gazet świadczy o głębokiej nienawiści do osób popełniających wykroczenia w wyniku chorób psychicznych. Dla dużej części społeczeństwa, a w szczególności tej, która często udziela się na forach internetowych, jednorazowe badanie i jednoznaczna diagnoza świadczą o chęci uniknięcia odpowiedzialności oraz powiązaniach rodziny z prokuraturą czy też biegłymi. Dowodzą tego przytoczone wpisy (zachowano oryginalną pisownię): „oni wszyscy są bardzo poczytalni, ciekawe ile biegli wzięli od mamusi”, „ma mamusie wysoko ustawioną to z synalka wariata zrobili żeby siedziec nie poszedł... ot co cała filozofia! Masz układy to ci g.... zrobią. Taka prawda chory kraj i system!”, „Od początku sprawy „wjechania” na Monciak, było widać,że sprawca nie odpowie za swój czyn. Pisząc o nim, pisano jaki jest inteligentny, obrotny i pracowity... Czy matka może chronić dorosłego łobuza? Przecieć: „niepoczytalny” jest terminem prawny a nie - medycznym...Słowem: napisano dużo, żeby pomóc sprawcy „polowania na ludzi” na Monciaku !!!”, „Człowiek niepoczytalny nie jest w stanie wykonać takich manewrów i tak kontrolować pojazd”, „skoro próbował uciekać z rozbitego samochodu to znaczy, że był poczytalny, wiedział że zrobił źle" [5].

Wśród komentarzy znalazł się jeden wpis tłumaczący działanie sprawcy chorobą psychiczną, jednak został on szybko wyśmiany.

Obserwatorzy internetowi oraz dziennikarze podważali słuszność opinii biegłych, a agresja, jaka towarzyszyła jej upublicznieniu, świadczyła o braku edukacji w zakresie chorób psychicznych. Jeden z dziennikarzy na łamach trójmiejskiego dziennika w ten sposób przedstawił zajście: „Z opisu zdarzenia wynika, że prawdopodobnie nie była to pomyłka ani chwilowe zamroczenie kierowcy, ani utrata sił umysłowych, ale zaplanowane działanie. Sposób kierowania przez sprawcę autem, który opisują świadkowie - jazda slalomem, żadnych prób omijania pieszych, brak oznak hamowania - może su- 
driving his car, as described by witnesses - driving in slalom, no attempts to avoid pedestrians, no signs of braking - may have suggested that the lunatic had aimed his vehicle at people" [6]. The incident was written about in a similar vein in another article: "Many witnesses of the Saturday incident emphasised that the driver had been driving his car in such a manner as if he had wanted to run over pedestrians with premeditation" [7]. At no point in their articles did the journalists take into account the possibility that the perpetrator had acted as a result of a mental illness.

It was as early as in 1996 that a press release concerning the results of research, conducted by the Centre for Public Opinion Surveys, on the lack of knowledge of both society and people cooperating with the media was published [1]. At the time, the authors pointed out that there was a stereotype of a mentally ill person alive in society, particularly one suffering from schizophrenia. This illness is usually treated in a deprecatory manner, the majority of names the ill are called regarding their stigmatisation. Most often, those names do not have anything to do with the characteristics of the ill, but they rather prove lack of knowledge on the illness.

We can arrive at similar conclusions by analysing later publications $[2,8]$. More often than not, the mentally ill are treated as dangerous, aggressive and unpredictable individuals. A large portion of society would want to have them isolated. Furthermore, the majority of people avoid any contact with mentally ill people as well.

Both the described case of the patient and the cited research results point to a deficit in knowledge within the category of mental illnesses. The contemporary media, which ensures us anonymity, enables the creation of distance and stigmatisation of the ill to an event greater extent. Lastly, what has been emphasised repeatedly is the need for education aimed at the general public. gerować, że szaleniec celował pojazdem w ludzi” [6]. Podobnie o zajściu mówiono w innym artykule: „Wielu świadków sobotniego zdarzenia podkreślało, że kierowca jechał samochodem w taki sposób, jakby z premedytacją chciał rozjechać przechodniów" [7]. Publicyści w żadnym fragmencie swych artykułów nie brali pod uwagę możliwości działania sprawcy w wyniku choroby psychicznej.

O braku wiedzy zarówno społeczeństwa, jak i osób współpracujących z mediami pisano już w komunikacie z badań Centrum Badania Opinii Społecznej z 1996 r. [1]. Autorzy wskazali wówczas na obecny w społeczeństwie stereotyp osoby chorej psychicznie, w szczególności na schizofrenię. Traktowana jest zwykle pejoratywnie, a większość określeń dotyczących osób chorych dotyczy ich stygmatyzacji. Najczęściej określenia te nie mają nic wspólnego z cechami osób chorych, ale świadczą o braku wiedzy na temat choroby.

Do podobnych wniosków można dojść, analizując późniejsze publikacje $[2,8]$. Chorzy psychicznie najczęściej traktowani są jako osoby niebezpieczne, agresywne i nieprzewidywalne. Duża część społeczeństwa chciałaby ich izolacji. Większość osób unika też kontaktu z osobami chorymi psychicznie.

Opisany przypadek, a także przytoczone wyniki badań wskazują na deficyt wiedzy w kategorii chorób psychicznych. Współczesne media, które zapewniają nam anonimowość, $w$ jeszcze większym stopniu umożliwiają wytworzenie dystansu i stygmatyzację osób chorych. Wielokrotnie podkreśla się potrzebę edukacji skierowanej do ogółu społeczeństwa.

\section{Conflict of interest/Konflikt interesu}

Absent./Nie występuje.

Financial support/Finansowanie

Absent./Nie występuje.

\section{References/Piśmiennicłwo}

1. Wciórka B, Wciórka J. Choroby psychiczne - społeczny stereotyp i dystans [Mental illnesses - Social stereotype and distance]. Post Psychiatr Neurol 1996; 5: 323-343.

2. Jackowska E. Stygmatyzacja i wykluczenie społeczne osób chorujących na schizofrenię - przegląd badań i mechanizmy psychologiczne [Stigmatisation and social exclusion of people suffering from schizophrenia - Research review and psychological mechanisms]. Psychiatr Pol 2009; 43: 655-670.

3. Angermeyer MC, Buyantugs L, Kenzine DV, Matschinger H. Effects of labelling on public attitudes towards people with schizophrenia: are there cultural differences? Acta Psychiatr Scand 2004; 109: 420-425.

4. Beldie A, den Boer JA, Brain C, Constant E, Figueira ML, Filipcic I, et al. Fighting stigma of mental illness in midsize European countries. Soc Psychiatry Psychiatr Epidemiol 2012; 47 (Suppl 1): 1-8. 
Public perception of a dangerous person in psychotic exacerbation on the example of a court expert judgement case

Społeczny odbiór niebezpiecznej osoby w zaostrzeniu psychotycznym na przykładzie przypadku orzeczniczego biegłych sądowych

5. http://www.gazetawroclawska.pl/artykul/3530083,sopot-kierowca-z-monciaka-byl-niepoczytalny-prokuratura -wymaga-leczenia,id,t.html

6. http://www.dziennikbaltycki.pl/artykul/3513117,wypadek-na-monciaku-w-sopocie-czy-taranowac-ludzi-mozna-nieumyslnie-komentarz,id,t.html

7. http://www.dziennikbaltycki.pl/artykul/3514489,szalenczy-rajd-na-monciaku-w-sopocie-co-grozi-michalowi-1 -ktory-ranil-23-osoby-zdjecia-wideo,1,id,t,sa.html

8. Mroczek B, Wróblewska I, Kędzierska A, Kurpas D. Postawy dorosłych Polaków wobec osób chorych psychicznie [Attitudes of adult Poles towards the mentally ill]. Fam Med Primary Care Rev 2014; 16: 263-265. 